A 204

\title{
強磁性ナノ微粒子挙動の暗視野可視化における ハイビジョンカメラの適用性
}

高橋 秀治○ (成蹊大院)，木倉 宏成(東工大)

有冨 正憲(東工大)，小川 隆申(成蹊大)

\section{Applicability of Hi-Vision video camera to ferromagnetic nano-particles visualization using darkfield microscopy}

\author{
Hideharu TAKAHASHI, Hiroshige KIKURA \\ Masanori ARITOMI, Takanobu OGAWA
}

\begin{abstract}
We are aiming at the development of an inexpensive system that can shoot, record, and analyze the minute world of nano-scale. As the first step, a new visualization system was built using a household high-definition video camera (HDR-HC3) and an optical microscope with the darkfield illumination. And, we evaluate its usage in ferromagnetic nano-particles visualization of magnetic fluid, and make sure its effectiveness in it.

Keywords: Hi-Vision video camera, ferromagnetic nano-particle, cluster formation darkfield microscopy, micro visualization
\end{abstract}

\section{1. 緒 論}

超高解像度のハイビジョン技術が, 次世代映像技術と してテレビ放送，映画，医療，教育等幅広い分野で活用 が期待される中，特に我が国で忏地上デジタル放送や 2005 年日本国際博覧会(愛知)で上映された走查線 4000 本級スーパーハイビジョン映像システム（NHK 放送技 術研究所) 等, 高精度 HD(High definition)映像一般 人が目にする機会が増えてきている。 そして，近年の八 イビジョンビデオカメラの技術革新仙目覚しく, 数年前 まで高価かつ業務用であったものが，最近では安価かつ 民生用で扱いが容易なものが市販されるようになってき た.

一方，近年のナノテクノロジーの進展に伴い，磁性流 体のような液体中の強磁性微粒子の巨視的振舞いが, 外 力による液体・伝熱制御の分野で関心を集めている，た とえば，(1)無磁場での強磁性微粒子のブラウン運動 (2) 外部磁場作用下での鎖状クラスタ一構造とその形成過程 の可視化と解明は, 磁性流体工学での異常粘性増加現象 の.問題解決に期待が寄せられている.

著者らはナノスケールの微小世界を可視化すると同時 に, PTV 解析などの画像解析に耐えうる画像を撮像・記 録できる安価なシステムの開発を目指している，その第 一歩として光学顕微鏡に民生用ハイビジョンビデオカメ ラ(HDR-HC3)を組み込んだ可視化システムを構築した.
民生用ハイビジョンビデオカメラの暗視野可視化にお ける適用性について, 磁性流体中の強磁性ナノ微粒子挙 動を対象として検討した。

\section{2. 実験装置および方法}

Fig.1 に実験装置の概略図を示す.供試体としてタイホ 一工業製水ベース磁性流体 W-40を使用した。 $76 \times$ $26 \mathrm{~mm}$ のスライドグラス上に, マイクロピペットで MF を $5 \mu 1$ 添加し， $22 \times 22 \mathrm{~mm}$ のカバーグラスで挟み込み 薄膜状（薄膜厚約 $10 \mu \mathrm{m}$ ) にしこれを試料とした。試料 を恒温プレート上 $\left(25^{\circ} \mathrm{C}\right)$ に設置し定常状態に保ってから オリンパス光学工業(株)製の生物顕微鏡(BX50)で観察し t. 磁性流体の分散粒子径は $10 \mathrm{~nm}$ 程度と可視光の波長 よりはるかに小さいため, 光学顕微鏡に油浸式暗視野コ ンデンサレンズを取り付け，粒子からの散乱光のみを対 物レンズを通して結像させる暗視野法 1)2)を用い水べー ス磁性流体の可視化を行った，対物レンズにはコニバー サルプラン・アポクロマート・レンズ(100x,oil iris)を用 い，中間レンズは 1.25 倍とした．またコンデンサレンズ とスライドグラス間，カバーガラスと対物レンズ間には ガラスと同屈折率のマッチングオイルを充填し光学精度 を高めた。 円筒型誘遵電磁石を試験領域両サイドに設置 し安定化電源より電流を印加して DC 磁場を発生させた. 
なお, 試料に対して X 軸方向に磁場を印加した (Fig.1).

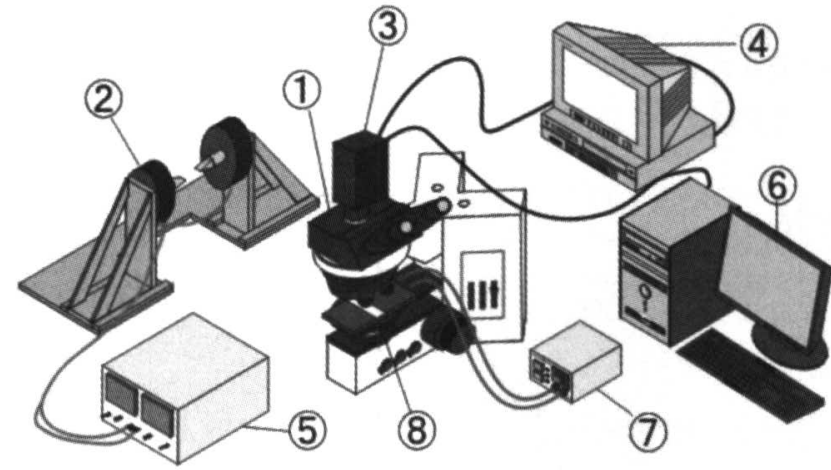

1. Microscope

2. Electro magnet

5. Stabilized power supply

3. Hi-vision video camera 7. Thermo-plate controller 4. Monitor 8. Test device

Fig. 1 Experimental apparatus

顕微鏡画像は鏡塔に固定した SONY 製民生用デジタ ルハイビジョンビデオカメラ（HDR HC-3）により撮影 した. 画像は HDV 形式 $(1440 \times 1080 \mathrm{pixel})$ でミニ DVテ ープに圧縮記録し，その後，パーソナルコンピュータに 取り込んだ。画像表示時には HDV 形式を補完し 1920 $\times 1080$ pixel(アスペクト比 16:9)とし扱った。

\section{3. 実験結果と考察}

暗視野顕微鏡法により，暗視野中の強磁性ナノ微粒子 を輝点として観測した。磁性流体中の強磁性微粒子のブ ラウン運動を可視化し，民生用ハイビジョンビデオカメ ラで撮影・記録した映像の 1 フレーム画像を Fig.2 に示 す．強磁性ナノ微粒子がブラウン運動している様子が記 録された．次に，水平方向に磁場 $\mathrm{B}=32 \mathrm{~m} \mathrm{~T}$ を印加する ことで鎖状クラスターが形成されている映像の 1 フレー 么画像を Fig.3 に示寸．磁場印加によって強磁性ナノ微 粒子が鎖状に凝集していく様子が観察された。また，鎖 状クラスター形成後に, 印加しているD C 磁場を解除し た際のクラスター崩壊時映像の 1 フレーム画像を Fig.4 に示す. 鎖状クラスターが分解していく様子が観察され, 粒子のブラウン運動により，しだいに，Fig.2 に示す分 散状態になった。これらの実験を通じ，磁場を印加する ことで, 水ベース磁性流体中の強磁性ナノ微粒子が鎖状 構造を形成し 2 次クラスターを形成する様子や, 磁場を 解除することで 2 次クラスタが崩壊する様子を民生用八 イビジョンビデオカメラにより撮像・記録できた。しか しながら，すべての画像において，四隅に画像のカケ・ 歪が見られた．ビデオカメラレンズが顕微鏡の光学系に 対し適当でないことが考えられる.

\section{4. 結言}

実験結果の観察を通じて，強磁性ナノ微粒子挙動の暗
視野可視化に民生用ハイビジョンカメラの適用が可能で あることが分かった。また，画像解析において画像の全 領域を使用する場合には，画像四隅のカケ・歪は問題と なり，今後，光学系の改良が必要である。

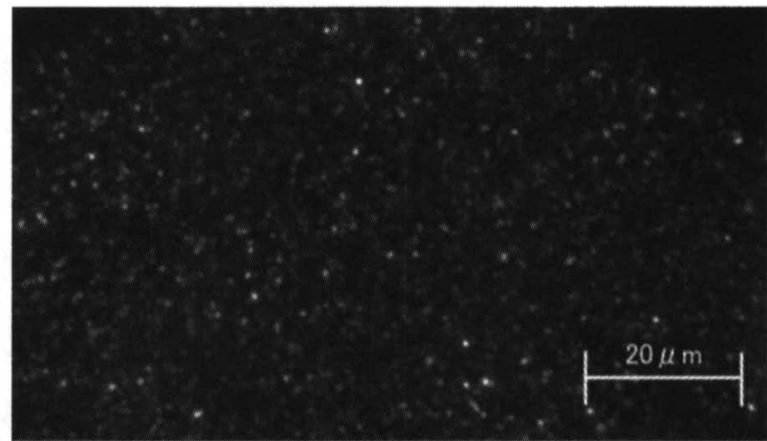

Fig. 2 Ferromagnetic particles brownian motion in a water-based magnetic fluid (W-40,1wt\%)

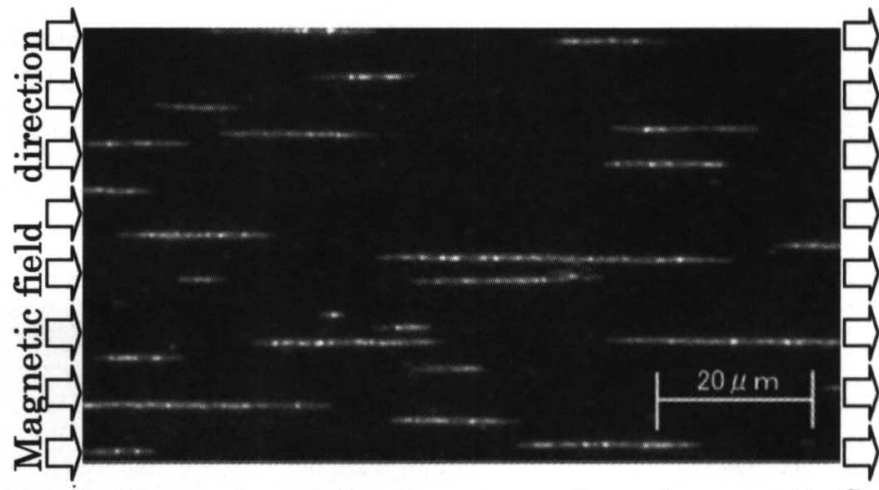

Fig. 3 Cluster formation in a water-based magnetic fluid under a magnetic field $\quad(\mathrm{W}-40,1 \mathrm{wt} \%, \mathrm{~B}=32 \mathrm{mT})$

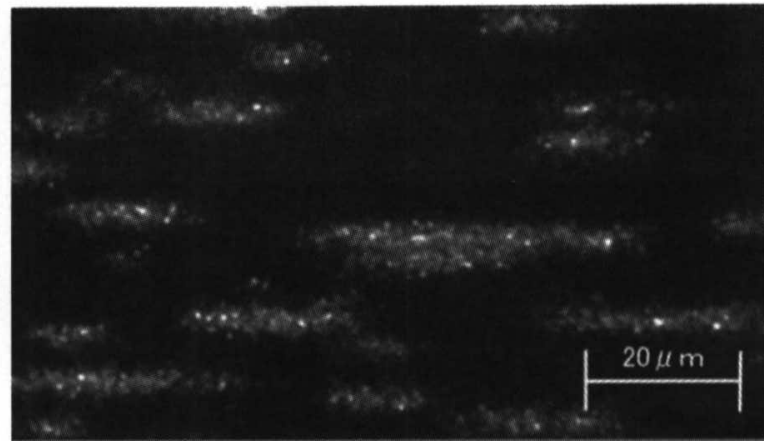

Fig. 4 Dispersion of cluster formation in a water-based magnetic fluid $\mathrm{W}-40,1 \mathrm{wt} \%$ )

参 考 文 献

1) I. Nakatani, Direct observation on Brownian motions and agglomeration of magnetic particles in magnetic fluids, Proc. Int. Symp. On Hydrodynamics of Mag. Fluid. And its Applications, 1997, pp. 9-12.

2) H. Kikura, et al., Flow visualization and particle size determination of primary clusters in a water based magnetic fluid, J. Magn. Magn. Mat., 2005, pp. 289, $392-395$ 